\title{
PENGEMBANGAN ASESMEN ALTERNATIF BERUPA PENILAIAN PRODUK PADA MATA KULIAH PEMBELAJARAN BAHASA JAWA DI SD
}

\author{
Endang Sri Maruti, Naniek Kusumawati \\ Universitas PGRI Madiun, marutiendang @gmail.com \\ Universitas PGRI Madiun, naniek@unipma.ac.id
}

\begin{abstract}
ABSTRAK
Pada mata kuliah Pembelajaran Bahasa Jawa di SD, mahasiswa tidak hanya dituntut untuk terampil dalam berbahasa Jawa dan tetapi juga harus terampil dalam mengajarkan Bahasa Jawa di SD. Untuk itu penilaian keterampilan merupakan komponen terpenting yang harus dilakukan oleh dosen untuk mengukur setiap detail keterampilan mahasiswa. Namun, kenyataannya penilaian dalam ranah ini belum dilakukan dengan menggunakan instrumen penilaian yang tepat, dosen masih melakukan proses penilaian secara langsung tanpa menggunakan instrumen sehingga penilaian lebih subjektif. Untuk itu, penelitian dan pengembangan produk instrumen penilaian keterampilan yang diintegrasikan dengan pemanfaatan teknologi perlu dilakukan. Instrumen penilaian produk berupa video desain pembelajaran bahasa Jawa yang dikembangkan dapat dijadikan solusi dan dapat dijadikan alternatif bagi dosen dalam melakukan proses penilaian keterampilan dalam pembelajaran Bahasa Jawa di SD. Penelitian pengembangan ini merujuk pada metode 4-D. Penelitian dimulai bulan Februari 2018 sampai November 2018. Data penelitian berupa hasil validasi. Adapun instrumen penelitian yang digunakan adalah lembar validasi dan angket respons siswa. Teknik pengumpulan data dengan teknik validasi dan observasi. Data dianalisis secara deskriptif kualitatif. Hasil penelitian menunjukkan skor rubrik penilaian dari validator untuk kategori struktur rubik adalah 3,67 (sangat baik), kategori organisasi penulisan aspek dalam rubrik penilaian adalah 4 (sangat baik), dan kategori bahasa adalah 4 (sangat baik). Dengan demikian, dapat disimpulkan bahwa rubrik penilaian dalam kategori baik dengan sedikit revisi dan dapat dapat digunakan.
\end{abstract}

Kata kunci: Instrumen penilaian produk, ranah keterampilan

\section{PENDAHULUAN}

Perkembangan zaman yang semakin modern menuntut peradaban untuk mengiringi dan mengimbangi transformasi kemajuan Teknologi Informasi dan Komunikasi (TIK) yang begitu pesat guna menyelaraskan hidup yang beriringan 
satu sama lain. Dalam dunia pendidikan, seperti diketahui bersama bagaimana peran teknologi yang semakin mengisi dan membantu guru dalam proses belajar mengajar untuk mendapatkan tujuan pembelajaran dapat dicapai secara maksimal. Dorongan teknologi yang memantapkan proses belajar mengajar agar suasana tidak monoton menjadi solusi yang banyak diterapkan oleh para pendidik dalam mengatur suasana pembelajaran yang kondusif.

Seperti diketahui bersama bahwa pendidikan merupakan sebuah pondasi bagi suatu bangsa, dalam mengembangkan dan meningkatkan mutu bangsa. Keberhasilan suatu pendidikan merupakan ciri dari kemajuan bangsa dimana bangsa yang maju adalah bangsa yang mampu memberikan ilmu pengetahuan kepada warga negaranya dengan baik melalui proses belajar mengajar hingga tercapainya tujuan pendidikan yang mampu mencetak generasi penerus sebagai pengubah keadaan bangsa menjadi lebih baik agar warga negaranya mampu hidup secara layak dan sejahtera.

Pendidikan yang berorientasi pada proses pembelajaran yang khususnya pada jenjang Sekolah Dasar (SD) hingga SMA dalam aplikasinya banyak ditunjang dengan vidio interaktif untuk mendorong semangat, antusiasme dan ketertarikan siswa dalam pembelajaran, yang mampu meningkatkan tercapainya hasil belajar secara maksimal. Pembelajaran yang didukung Teknologi Informasi dan Komunikasi di sekolah mampu meningkatkan kreativitas siswa dan menunjang keahlian guru untuk mampu memberikan pembelajaran semenarik mungkin.

Sebagai contoh pemanfaatan media pembelajaran pada mata kuliah Pembelajaran Bahasa Jawa di SD yang awalnya dianggap tradisional dan kurang modern, nyatanya bisa diubah menjadi perkuliahan yang berbasis TIK yang menjadikan suasana dalam kelas menjadi terkontrol. Banyak media pembelajaran berbasis multimedia yang biasa digunakan dalam proses perkuliahan Bahasa Jawa seperti CorelDraw, Ulead, Move Maker, Vidio interaktif dan lain sebagainya. 
Untuk memenuhi tuntutan zaman, dosen memulai terobosan baru dengan mengolah kemampuan mahasiswa dengan menggunakan penilaian produk. Penilaian produk atau hasil kerja adalah penilaian terhadap keterampilan siswa dalam membuat suatu produk benda tertentu dan kualitas produk tersebut. Jadi dalam penilaian hasil kerja siswa terdapat dua tahapan penilaian yaitu (1) Penilaian tentang pemilihan dan cara penggunaan alat serta prosedur kerja siswa; (2) Penilaian tentang kualitas teknis maupun estetik hasil karya/kerja siswa.

Hasil kerja yang dimaksud di sini adalah produk kerja siswa yang bisa saja terbuat dari kain, kertas, metal, kayu, plastik, keramik, dan hasil karya seni seperti lukisan, gambar, dan patung. Hasil kerja yang berupa aransemen musik, koreografi, karya sastra tidak termasuk hasil kerja yang dimaksud di sini. Jadi dalam pembelajaran bahasa Jawa nanti, mahasiswa diberikan tugas membuat produk yang memanfaatkan aplikasi ulead vidio studio.

Perkuliahan Pembelajaran bahasa Jawa di SD menggunakan Ulead Vidio Studio membuat proses pembelajaran menarik (tidak monoton), dan mampu melatih kreativitas mahasiswa dalam menyiapkan materi ajar yang nantinya diajarkan pada murid SD. Maka dari itu pembelajaran secara konvensional tidak akan lagi mampu memberikan pelayanan terbaik untuk proses pembelajaran khususnya dalam pembelajaran Bahasa Jawa. Begitu juga pendekatan-pendekatan modern yang digunakan dalam pengajaran tidak akan banyak membantu mengejar ilmu pengetahuan yang semakin berkembang dengan berarahkan pada era teknologi.

\section{Metode}

Penelitian ini adalah penelitian pengembangan. Penelitian dan pengembangan merupakan suatu proses atau langkah-langkah yang dilakukan untuk mengembangkan suatu produk baru atau menyempurnakan produk yang 
telah ada, dan dapat dipertanggungjawabkan (Sukmadinata, 2005:164). Penelitian ini menghasilkan produk yang berupa alat evaluasi alternatif berupa alat penilaian produk yang memanfaatkan aplikasi ulead vidio studio pada perkuliahan Pembelajaran bahasa Jawa di SD. Penelitian pengembangan ini mengacu pada model pengembangan 4-D (four $D$ model) yang terdiri dari empat tahap (Thiagarajan \& Semmel, 1974) yaitu, pendefinisian (define), perancangan (design), pengembangan (develop), dan penyebaran (disseminate). Subjek penelitian adalah mahasiswa prodi PGSD Universitas PGRI Madiun semester V tahun pelajaran 2017/2018 yang melibatkan 150 mahasiswa. Teknik pengumpulan data digunakan untuk memperoleh bahan-bahan yang relevan, akurat, dan dapat digunakan dengan tepat sesuai tujuan penelitian. Teknik pengumpulan data yang digunakan dalam penelitian ini adalah: (1) pengamatan; (2) dokumentasi; dan (3) angket.

\section{Teknik Analisis Data}

Data untuk proses pengembangan alat evaluasi alternatif berupa alat penilaian produk yang memanfaatkan aplikasi ulead vidio studio pada perkuliahan Pembelajaran Bahasa Jawa di SD pada mahasiswa semester V Prodi PGSD, Universitas PGRI Madiun digunakan teknik validasi. Teknik validasi dilakukan oleh tim validator ahli. Masukan dan saran dari tim validator digunakan sebagai salah satu rujukan untuk merevisi bahan ajar.Untuk memperoleh data tersebut digunakan teknik deskriptif. Lembar instrumen validasi diisi oleh validator ahli kemudian peneliti menganalisis lembar instrumen validasi tersebut. Masukan dan saran dari tim validator digunakan sebagai salah satu rujukan untuk merevisi produk.

Teknik deskriptif dilakukan mulai dari tahap pendefinisian hingga tahap pengembangan, sedangkan untuk menganalisis hasil validasi dari validator dianalisis dengan teknik deskriptif kualitatif dengan kriteria rata-rata hasil validasi 
ahli yaitu bisa dilihat pada tabel 3.2. Demikian juga dengan persentase skor kelayakan juga berdasarkan interpretasi perhitungan skala likert tabel 3.1 berikut ini:

Tabel 3.1 Skala Likert

\begin{tabular}{|c|c|}
\hline Penilaian & Skala Nilai \\
\hline Sangat Baik & 5 \\
\hline Baik & 4 \\
\hline Cukup & 3 \\
\hline Kurang & 2 \\
\hline Sangat Kurang & 1 \\
\hline
\end{tabular}

(Riduwan, 2003:39)

Untuk menganalisis hasil validasi dari validator, dianalisis dengan teknik deskriptif kualitatif. Data yang diperoleh dianalisis dengan deskriptif kualitatif dengan merata-rata skor tiap aspek. Hasil penskoran dideskripsikan sebagai berikut:

Tabel 3.2 Kriteria rata-rata hasil validasi ahli

\begin{tabular}{|l|l|l|}
\hline \multicolumn{1}{|c|}{ Rata-Rata Nilai } & \multicolumn{1}{|c|}{ Klasifikasi } & \multicolumn{1}{c|}{ Kesimpulan } \\
\hline $1,0 \leq \mathrm{SV}<1,5$ & Tidak Baik & belum dapat digunakan \\
\hline $1,6 \leq \mathrm{SV}<2,5$ & Kurang Baik & dapat digunakan dengan merevisi besar \\
\hline $2,6 \leq \mathrm{SV}<3,5$ & Baik & dapat digunakan dengan merevisi kecil \\
\hline $3,6 \leq \mathrm{SV}<4,0$ & Sangat Baik & dapat digunakan tanpa revisi \\
\hline
\end{tabular}

(Ratumanan dan Laurens, 2006)

159 | http://journal.unesa.ac.id/index.php/paramasastra 


\section{HASIL DAN PEMBAHASAN}

Adapun tujuan dari penelitian ini adalah untuk (1) mendiskripsikan proses pengembangan assesmen alternatif berupa penilaian produk dengan memanfaatkan aplikasi ulead vidio studio pada mata kuliah Pembelajaran Bahasa Jawa di SD, (2) mendeskripsikan kualitas assesmen alternatif berupa penilaian produk dengan memanfaatkan aplikasi ulead vidio studio pada mata kuliah Pembelajaran Bahasa Jawa di SD. Berikut ini uraian setiap langkah dan hasil yang telah diperoleh dalam setiap tujuan penelitian tersebut.

\section{Proses Pengembangan Asessmen Alternatif Berupa Aplikasi Ulead Vidio Studio}

Secara garis besar, proses pengembangan assesmen alternatif berupa aplikasi ulead vidio studio pada mata kuliah Pembelajaran Bahasa Jawa di SD terdiri dari tiga tahap. Tahap tersebut adalah tahap pendifinisian, tahap perancangan, dan tahap pengembangan. Pada tahap pendefinisian ini dilakukan beberapa tahapan, yaitu analisis awal akhir, analisis siswa, analisis konsep, analisis tugas, dan analisis tujuan pembelajaran. Tahap perancangan bertujuan untuk mendapatkan format atau draft awal assesmen alternative berupa rubrik penilaian produk yang dikembangkan. Rubrik penilaian produk yang dikembangan, memperhatikan struktur rubrik, organisasi penulisan aspek dalam rubrik penilaian, dan bahasa. Rubrik penilaian produk yang telah dikembangkan kemudian disusun dan dibaca ulang sebagai kegiatan penyuntingan. Kegiatan ini dilakukan dengan tujuan apabila terdapat kesalahan bahasa dan ejaan dapat diperbaiki. Rubrik penilaian produk yang dihasilkan merupakan draf I.

Tahap Pengembangan ini bertujuan untuk menghasilkan rubrik penilaian produk atau assesmen alternatif berbasis ulead vidio studio pada mata kuliah Pembelajaran Bahasa Jawa di SD. Draf I yang telah disusun dilakukan validasi oleh validator ahli. Berdasarkan masukan dari validator draf I rubrik penilaian 
produk hasil pengembangan direvisi. Rubrik penilaian produk hasil revisi disebut draf II. Draf II tersebut kemudian diuji coba terbatas. Sebelum pelaksanaan uji coba terbatas subjek dites untuk mengetahui kemampuan awal subjek. Setelah uji coba terbatas dilakukan, subjek diwawancarai dan dilakukan tes untuk mengetahui pemahaman penilaian produk ke mahasiswa terhadap pembelajaran yang telah berlangsung. Setelah uji coba terbatas dilakukan, rubrik penilaian produk yang dikembangkan direvisi sesuai dengan hasil uji coba terbatas. Hasil tersebut disebut draf III. Draf III diuji coba secara luas. Setelah uji coba luas dilakukan, subjek diwawancarai dan dilakukan tes untuk mengetahui pemahaman penilaian produk ke mahasiswa terhadap pembelajaran yang telah berlangsung. Setelah uji coba luas dilakukan rubrik penilaian produk yang dikembangkan direvisi sesuai dengan hasil uji coba luas. Hasil dari wawancara dan hasil tes dipakai sebagai bahan pertimbangan untuk memperbaiki draf rubrik penilaian produk atau assesmen alternatif berbasis ulead vidio studio. Dengan demikian draf IV merupakan hasil pengembangan rubrik penilaian produk atau assesmen alternatif dengan memanfatkan atau berbasis ulead vidio studio.

Tahap penyebaran merupakan tahap akhir yang dilakukan peneliti untuk menyebarkan rubrik penilaian produk yang ditelah selesai dibuat. Penyebaran hasil pengembangan rubrik penilaian produk atau assesmen alternatif dengan memanfaatkan aplikasi ulead vidio studio tersebut dilakukan pada saat melakukan kegiatan rapat asosiasi dengan para dosen atau pendidik Bahasa Jawa di tingkat lokal atau nasional, workshop-workshop terkait media pembelajaran di kampus, pada saat mengikuti seminar nasional atau internasional terkait media pembelajaran.

161 | http://journal.unesa.ac.id/index.php/paramasastra 
Kualitas Pengembangan Assesmen Alternatif Berupa Aplikasi Ulead Vidio Studio

Kualitas hasil rubrik penilaian produk atau assesmen alternatif dengan memanfatkan aplikasi ulead vidio studio yang dikembangkan dapat ditentukan dari hasil validasi ahli. Secara keseluruhan, perangkat tersebut divalidasi berdasarkan tiga hal, yaitu berdasarkan struktur rubrik, organisasi penulisan aspek dalam rubrik penilaian, dan bahasa.

\section{Validasi Rubrik Penilaian Produk Berdasarkan Ahli}

Adapun hasil penilaian validator ahli terhadap kelayakan rubrik penilaian berdasarkan isinya disajikan pada Tabel 4.1 berikut.

\begin{tabular}{|c|c|c|c|}
\hline No & Aspek Yang Dinilai & $\begin{array}{c}\text { Skala } \\
\text { Penilaian }\end{array}$ & $\begin{array}{c}\text { Rata-Rata } \\
\text { Aspek }\end{array}$ \\
\hline \multirow[t]{5}{*}{$\mathbf{I}$} & STRUKTUR RUBRIK & & \\
\hline & 1. Organisasi penyajian secara umum & 4 & \\
\hline & 2. Tampilan umum menarik & 3 & \\
\hline & 3. Keterkaitan yang konsisten antara materi & 4 & \\
\hline & Rata-Rata Skor & & 3,67 \\
\hline \multirow[t]{5}{*}{ II } & $\begin{array}{l}\text { ORGANISASI PENULISAN ASPEK } \\
\text { DALAM RUBRIK PENILAIAN }\end{array}$ & & \\
\hline & 1. Cakupan aspek & 4 & \\
\hline & 2. Kejelasan dan urutan aspek & 4 & \\
\hline & $\begin{array}{l}\text { 3. Ketepatan aspek dengan capaian } \\
\text { pembelajaran }\end{array}$ & 4 & \\
\hline & Rata-Rata Skor & & 4 \\
\hline \multirow[t]{2}{*}{ III } & BAHASA & & \\
\hline & 1. Penggunaan bahasa sesuai EYD & 4 & \\
\hline
\end{tabular}




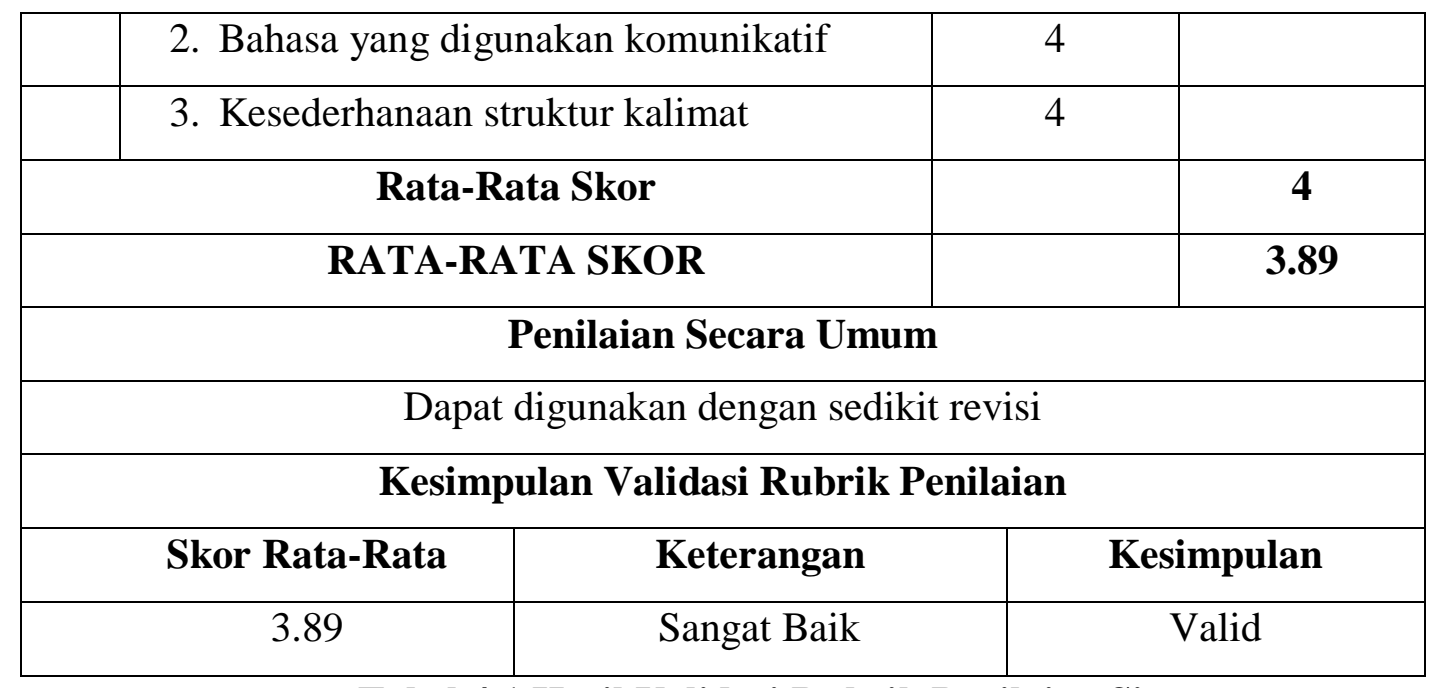

Tabel 4.1 Hasil Validasi Rubrik Penilaian Siswa

Dari Tabel 4.1 menunjukkan rata-rata skor rubrik penilaian dari validator untuk kategori struktur rubik adalah 3,67 (sangat baik), kategori organisasi penulisan aspek dalam rubrik penilaian adalah 4 (sangat baik), dan kategori bahasa adalah 4 (sangat baik). Validasi pakar/ahli menunjukkan bahwa secara keseluruhan rubrik penilaian atau assesmen alternatif berupa penilaian produk dengan memanfaatkan aplikasi ulead vidio studio pada mata kuliah Pembelajaran Bahasa Jawa di SD termasuk dalam kategori sangat baik dengan skor rata-rata 3.89, hanya dengan sedikit revisi maka rubrik penilaian atau assesmen alternatif dengan memanfaatkan aplikasi ulead vidio studio dapat diterapkan dalam kegiatan belajar mengajar. Berdasarkan analisis hasil validasi pakar dapat disimpulkan bahwa assesmen alternatif dengan memanfaatkan aplikasi ulead vidio studio yang dikembangkan layak digunakan sebagai rubrik penilaian karena sudah memenuhi standar validitas yang ditentukan oleh Badan Standar Nasional Pendidikan (BSNP). 


\section{Respon Siswa}

Untuk memperoleh data tentang bagaimana respons mahasiswa setelah penerapan pembelajaran maka digunakan lembar angket. Dari angket yang respons siswa yang telah diisi oleh siswa yang mengikuti pembelajaran, maka diperoleh hasil seperti pada tabel 4.2 berikut.

\begin{tabular}{|c|c|c|c|c|c|}
\hline No & Uraian Pertanyaan & \multicolumn{4}{|c|}{ Respon } \\
\hline \multirow[t]{6}{*}{1} & \multirow{2}{*}{$\begin{array}{l}\text { Bagaimana pendapat anda tentang } \\
\text { komponen-komponen berikut ini }\end{array}$} & \multicolumn{2}{|c|}{ Tertarik } & \multicolumn{2}{|c|}{ Tidak Tertarik } \\
\hline & & Frekwensi & $\%$ & Frekwensi & $\%$ \\
\hline & a. Materi/ Isi Pelajaran & 135 & 100 & 15 & 100 \\
\hline & $\begin{array}{l}\text { b. Suasana dan Cara Mengajar } \\
\text { Guru }\end{array}$ & 130 & 100 & 20 & 100 \\
\hline & c. Media Pembelajaran & 140 & 100 & 10 & 100 \\
\hline & Rata-rata & & $90 \%$ & & $10 \%$ \\
\hline \multirow[t]{6}{*}{2} & Apakah anda merasa baru dengan & \multicolumn{2}{|c|}{ Baru } & \multicolumn{2}{|c|}{ Tidak Baru } \\
\hline & komponen-komponen berikut ini & Frekwensi & $\%$ & Frekwensi & $\%$ \\
\hline & a. Materi/ Isi Pelajaran & 137 & 100 & 13 & 100 \\
\hline & b. Suasana dan Cara Mengajar Guru & 140 & 100 & 10 & 100 \\
\hline & c. Media Pembelajaran & 143 & 100 & 7 & 100 \\
\hline & Rata-rata & & $93 \%$ & & $7 \%$ \\
\hline 3 & Apakah anda dengan mudah & \multicolumn{2}{|c|}{ Mudah } & \multicolumn{2}{|c|}{ Tidak Mudah } \\
\hline
\end{tabular}




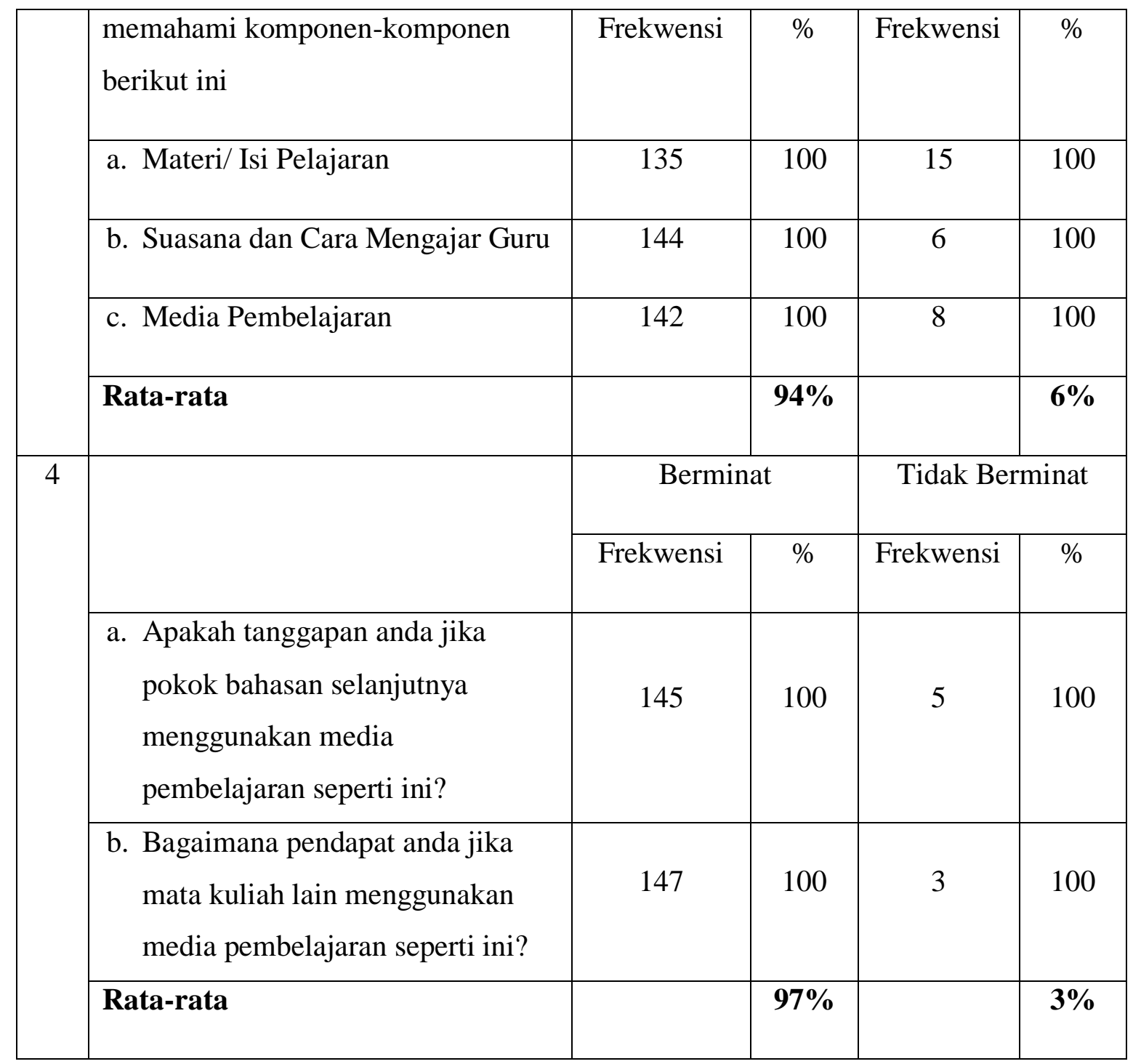

Tabel 4.2 Data Pengamatan Respons Mahasiswa

Tabel 4.2 di atas menjelaskan tentang respons mahasiswa terhadap proses pembelajaran Bahasa Jawa dengan memanfaatkan aplikasi ulead vidio studio. Respons mahasiswa diperoleh dari angket respons mahasiswa yang diberikan kepada setiap mahasiswa setelah mengikuti pembelajaran Bahasa Jawa dengan memanfaatkan aplikasi ulead vidio studio. Berdasarkan tabel di atas, diketahui 
tanggapan mahasiswa tentang perasaannya saat mengikuti pembelajaran Bahasa Jawa dengan memanfaatkan aplikasi ulead vidio studio yang meliputi komponenkomponen seperti: materi/isi pelajaran, suasana belajar dan cara guru mengajar juga penggunaan media didalam kelas. Berdasarkan ketiga komponen tersebut, rata-rata sebanyak 140 mahasiswa atau hampir 90\% mahasiswa senang dengan materi yang diajarkan, dan hanya 10 mahasiswa atau $10 \%$ saja yang mengaku tidak senang. Materi yang menarik dikombinasi dengan penggunaan media berbasis aplikasi ulead vidio studio, membuat mahasiswa menjadi tertarik dan lebih menghidupkan lagi suasana belajar.

Hal serupa juga terjadi pada respons mahasiswa terhadap kebaruan media pembelajaran yang digunakan. Dari 140 siswa yang mengikuti ujicoba, hanya sepuluh pula mahasiswa atau $10 \%$ mahasiswa saja yang berpendapat bahwa kebaruan aplikasi ulead vidio studio untuk mata kuliah Pembelajaran Bahasa Jawa tidak baru. Dengan demikian dapat dikatakan bahwa 90\% mahasiswa berpendapat bahwa penggunaan media dengan memanfaatkan aplikasi ulead vidio studio pada mata kuliah Pembelajaran Bahasa Jawa merupakan suatu kebaruan media pembelajaran yang patut untuk mereka pelajari.

Dari segi kemudahan penyampaian materi, suasana dan cara guru mengajar juga penggunaan media terkait dengan aplikasi ulead vidio studio merupakan suatu hal yang mudah untuk dipahami. Hal itu terbukti dari 140 mahasiswa dari 150 mahasiswa atau sebanyak 94\% mahasiswa menyetakan mudah memahami dan mengaplikasikan media pembelajaran dengan menggunakan aplikasi ulead vidio studio. Sisanya, hanya 6\% saja yang mengaku tidak mudah dengan aplikasi ulead vidio studio yang dikembangkan.

Respons siswa yang terakhir adalah tentang minat mereka untuk menggunakan media pembelajaran dengan memanfaatkan aplikasi ulead vidio studio ini pada materi selanjutnya. Berdasarkan data yang diperoleh, sebanyak 146 mahasiswa atau sebanyak 97\% mahasiswa menyatakan berminat untuk 
menggunakan media berbasis aplikasi ulead vidio studio ini untuk materi selanjutnya. Sisanya, hanya 4 mahasiswa saja atau sebanyak 3\% yang menyatakan tidak berminat dengan adanya penggunaan media pembelajaran berbasis aplikasi ulead vidio studio untuk materi atau bab selanjutnya.

Berdasarkan keempat respons mahasiswa terhadap pembelajaran Bahasa Jawa dengan memanfaatkan aplikasi ulead vidio studio di atas, menyatakan jika aplikasi ulead vidio studio dalam Pembelajaran Bahasa Jawa merupakan hal yang menyenangkan, menarik, menambah minat belajar, mudah dipahami, suatu kebaharuan dan sangat bermanfaat untuk menunjang proses kegiatan belajar mengajar dikelas dan disetujui siswa untuk diterapkan dalam kegiatan pembelajaran.

\section{SIMPULAN}

Berdasarkan hasil analisis, diskusi, dan pembahasan, maka dapat dibuat kesimpulan bahwa pengembangan rubrik penilaian atau assesmen alternatif dengan memanfaatkan aplikasi ulead vidio studio sudah valid untuk diterapkan atau digunakan pada proses pembelajaran khususnya pada mata kuliah Pembelajaran Bahasa Jawa di SD. Dan kedepannya diharapkan juga bisa digunakan pada mata kuliah lainnya. Saran yang dapat dikemukakan oleh peneliti berdasarkan penelititan yang telah dilakukan adalah pengembangan rubrik penilaian sebaiknya juga memperhatikan sifat konstekstual objek, benda, atau fenomena yang digunakan bagi para mahasiswa, sehingga dapat membangkitkan pengetahuan yang sudah dimiliki untuk memahami pengetahuan baru yang hendak dipelajari. 


\section{DAFTAR PUSTAKA}

Ahmadi dan Amri. 2010. Konstruksi Pengembangan Pembelajaran. Jakarta : Prestasi Pustaka.

Arikunto, Suharsimi. 2006. Prosedur Pengembangan : Suatu Pendekatan Praktik Edisi Revisi VI. Jakarta: Rineka Cipta.

Depdiknas. 2006. Pedoman Memilih dan Menyusun Bahan Ajar. Jakarta: Derektorat SMP, Derektorat jenderal Manajemen Pendidikan Dasar dan Menengah, Depdiknas.

Depdiknas. 2008. Panduan Pengembangan Bahan Ajar. Jakarta: Depdiknas.

Ibrahim, Muslimin.2001. Model Pembelajaran Perangkat Menurut Jerolg E. Kemp \& Thiagarajan. Surabaya: Faculty of Matematics and Science University Assosiates.

Meier, Dave.2002. The Accelerated Learning Handbook. Bandung: MMU (Mizan Media Utama).

Ratumanan, G.T, dan T. Laurens. 2006. Evaluasi Hasil Belajar Ynag Relevan Dengan Memecahkan Problematika Belajar dan Mengajar. Bandung: CV. Alfabeta.

Riduwan. 2003. Skala Pengukuran Variabel-Variabel Peneltian. Bandung: Alfabeta.

Riduwan. 2003. Dasar-dasar Statistika. Bandung: Alfabeta.

Sukmadinata, Nana Syaodih. 2005. Metode Penelitian Pendidikan. Bandung: Bandung Rosdakarya.

Trianto. 2007. Model Pembelajaran Terpadu dalam Teori dan Praktik. Jakarta: Prestasi Pustaka.

Trianto. 2011. Model Pembelajaran Terpadu: Konsep, Strategi, dan Implementasinya dalam Kurikulum Tingkat Satuan Pendidikan (KTSP). Jakarta: Bumi Aksara. 
Endang Sri Maruti dan Naniek Kusumawati, Pengembangan Asesmen... (hlm.155-169)

Prawiradilaga, Salma, Dewi. 2007. Prinsip Desain Pembelajaran Instructional Design Principles. Jakarta: Kencana Prenada Media Group.

169 | http://journal.unesa.ac.id/index.php/paramasastra 